\title{
DO BANKS OR VCS SPUR SMALL FIRM GROWTH?
}

\section{Rebel Cole}

DePaul University, Dept. of Finance, 14 E. Jackson Blvd. - Suite 900, Chicago, IL 60604 USA

http://ssrn.com/author=15769

rcole@depaul.edu

\section{Douglas Cumming}

York University, Schulich School of Business, 4700 Keele Street, Toronto, ON, M3J 1P3, Canada

http://ssrn.com/author $=75390$

douglas.cumming@gmail.com

\section{Dan Li}

The School of Economics and Finance, University of Hong Kong, 8th Floor Kennedy Town Centre, 23

Belcher's Street, Kennedy Town, Hong Kong

http://ssrn.com/author=868088

lidan@hku.hk

This draft: 30 October 2014

\footnotetext{
* We are indebted to Ming Dong, Katrin Hussinger, Gordon Roberts and Pauline Shum, and the IFN Conference on the Economics of Ownership, Organization and Industrial Development in Vaxholm, Sweden, the American Law and Economics Association, Princeton, the Third Annual Searle Research Symposium on the Economics and Law of the Entrepreneur at Northwestern University, the European Financial Management Association Annual Conference in Aarhus, Denmark, the European Financial Management Association Meeting on Alternative Investments in Toronto, the Milan VICO Conference, the Conference on Business Creation at George Washington University, and the Kauffmann Empirical Entrepreneurship Conference, Philadelphia, and the Eastern Finance Association, Boston, and the University of Hong Kong, and York University Schulich School of Business.
} 


\title{
Do BANKS OR VCS SPUR SMALL FIRM GROWTH?
}

\begin{abstract}
It is well accepted that access to entrepreneurial finance encourages entrepreneurship and growth. Empirical studies on topic, however, segregate the effect of entrepreneurial finance on entrepreneurship by the source of capital. In this paper, we compare the effect of two main sources of entrepreneurial finance small firm formation and growth: banks versus venture capital (VC). Based on U.S. data spanning 1995-2011, and regardless of controls for endogeneity, we find the effect of VC to be both economically and statistically significant in stimulating new firms, new establishments, new employment, and new payroll. We do not find similar evidence for banks.
\end{abstract}

Keywords: Banks, Venture Capital, Growth, Entrepreneurship

JEL Codes: L26, L50, K31, K35, G24 


\section{Introduction}

It is well accepted that access to capital stimulates entrepreneurship (World Bank, 2004; Keuschnigg, 2004; Audretsch, 2007a,b; Engel and Keilbach, 2006; Klapper et al., 2006; Audretsch and Keilbach, 2007). There are relatively few studies, however, that compare different sources of entrepreneurial finance in stimulating entrepreneurial activity. One literature shows a strong role for banks in stimulating new firm formation and growth (e.g., Berger and Black, 2011; DeYoung, 2009). A second literature shows the importance of venture capital (VC) in stimulating new firm formation and growth (e.g., Bertoni et al., 2011; Samila and Sorrensen, 2009; Wang and Wang, 2012; Yung, 2009). Relatively few empirical studies simultaneously document the differences between VC and banks, largely because datasets on entrepreneurial finance are often derived from the source of capital; some exceptions include recent work by Berger and Schaeck (2011), Chavis et al. (2011), Cosh et al. (2009) and Robb and Robinson (2014).

An unexplored question in the literature involves comparing the relative importance of VC versus banks in stimulating entrepreneurship. Prior literature (e.g., Keuschnigg, 2004; Gompers and Lerner, 1999) is consistent with the view that VC's provide comparatively more value-added support to entrepreneurs relative to banks, including but not limited to sitting on boards of directors, offering strategic, managerial, human resource, marketing, and financial advice, and providing a network of strategic alliances with suppliers, customers, legal and accounting advisors, as well as investment banks in the event that the firm seeks public listing. Terms upon which VC-backed firm goes public are typically better than that for non-VC backed firms. These considerations all suggest that VC plays a more pronounced role than banks in 
spurring entrepreneurs. On the other hand, VC is comparatively hard to obtain and bank finance is much more readily available (Cosh et al., 2009; Robb and Robinson, 2014). The relative dearth of VC finance to bank finance suggests that bank finance is comparatively more important than VCs in spurring entrepreneurs. All things considered, therefore, it is difficult to know a priori whether VCs or banks are relatively more important in spurring entrepreneurship and growth without empirical testing.

In this paper, we analyze the relative importance of banks versus VCs in spurring entrepreneurship using annual U.S. state level panel data spanning the period 1995-2011. We consider four main indicators of entrepreneurship: the annual number of new firms, the annual number of new establishments, annual new firm employment, and annual new firm payroll. We control for various factors that might influence entrepreneurial activity across states and over time, such as growth in personal income, population, education, government policy, and patents, among other things.

An empirical issue that arises in assessing the impact of banks versus VC on entrepreneurship is endogeneity. Bank finance and VC finance may stimulate entrepreneurship by facilitating access to capital for the financing of new ideas and value-added professionalization and governance provided by the investors. At the same time, however, banks and venture capitalists (VCs) may move to areas where rates of entrepreneurship are expected to be more favorable in the future. VCs may stimulate invention, but they have also been noted for chasing good inventive ideas (Gompers and Lerner, 1999; Hirukawa and Ueda, 2008). The boom-and-bust periods with VC have been particularly pronounced as market cycles move up and down, thereby suggesting the impact of VC finance on entrepreneurship could be particularly prone to issues of endogeneity. 
Following the approach used in related work in bank finance (Black and Strahan, 2002) and VC finance Samila and Sorenson, 2010), we assess and control for causality issues by instrumenting VC finance on returns to institutional investors, and instrumenting bank finance on bank assets, capital and deposit-to-asset ratio. The instrumental-variable estimates show very consistent results for both bank and VC finance, albeit with some exceptions that are noted herein.

The US state level panel data over 1995-2011 indicate the following. First, for the smallest firms with fewer than 4 employees, we see scant evidence that either VC or bank finance spurs growth in firms, establishments, employment, or payroll. Instead, growth in firms, establishments, employment, and payroll is caused by growth in personal income, higher levels of education, fewer labor restrictions, and more SBIR awards. These findings are consistent with prior work on topic based on earlier datasets.

Second, for firms with 5-19 employees, the impact of VC on growth is consistently positive and significant. This effect is statistically significant regardless of our controls for endogeneity. The economic significance of the effect is large. For instance, after controlling for endogeneity, a $10 \%$ increase in VC is associated with a $2.6 \%$ increase in the number of firms, a $2.3 \%$ increase in the number of establishments, a $2.9 \%$ increase in number of employees, and a 3.9\% increase in total payroll. By contrast, there is no apparent or statistically significant impact of banks on any of these outcome variables.

Third, for firms with 20-99 employees, the impact of VC on growth is not nearly as robust. There is some evidence of a positive effect of VC on new firms, and no evidence of an effect of VC on establishments and employees. There is evidence of a positive effect of VC on payroll that is robust and significant at at least the $5 \%$ level, whereby a $10 \%$ increase in VC 
causes a $5.9 \%$ increase in total payroll. For banks, the evidence is not robust to the use of instrumental variables, although there is some suggestive evidence of a positive impact on establishments and payroll.

The question of whether banks or VCs are more important for stimulating entrepreneurship is one that is important for academic research, practice and policymakers alike. In recent years, there has been a relative shift in the focus of academic studies towards VCs as a primary source of entrepreneurial finance, despite the fact that most entrepreneurs do not obtain VC and the predominant source of capital is bank finance (Cosh et al., 2009; Robb and Robinson, 2014). By directly comparing the effect of VC versus banks on stimulating entrepreneurship, we offer insight into whether or not this shift is warranted. To this end, we also provide guidance to practitioners and policymakers by examining whether or not one form of capital versus another is relatively more deserving of tax subsidization. Our evidence is consistent with the importance of VC for growth (Keuschnigg, 2004) and the important role of public policy in stimulating VC markets to encourage economic growth (Keuschnigg and Nielsen, 2001, 2003a,b, 2004a,b,c).

This paper is organized as follows. A description of the data and summary statistics are provided in section 2. Section 3 presents multivariate tests with ordinary panel data estimates. Section 4 presents estimates with instrumental variables. Section 5 discusses additional robustness checks. The last section concludes. 


\section{Data}

We empirically analyze how entrepreneurial activity is related to the two forms of financing: small-business bank loans and VC investments. Our analysis uses a balanced panel of 50 states in the United States from 1995 to $2011^{1}$. Considering that the focus of the paper is on entrepreneurial activity, we focus the paper on small businesses with fewer than 100 employees, on which we acquire data from the Statistics of U.S. Businesses (SUSB) dataset constructed by the U.S. Census Bureau. ${ }^{2}$ These data are summarized in Table 1, along with variable definitions. The annual SUSB data provide information at the U.S. state level on the number of firms, the number of establishments, employment, and annual payroll by firm employment size category. An establishment is defined as a single physical location where business is conducted or where services or industrial operations are performed. A firm is defined as an aggregation of all establishments owned by a parent company within a state. Most firms in the sample are composed of only single establishments. ${ }^{3}$ Therefore, the two variables are only slightly different

\footnotetext{
${ }^{1}$ Our sample period begins at 1995 because the small business lending data, which is from the Report of Condition and Income (informally known as the "Call Report"), are not available until 1993. We compute the growth rate of small bank loan (Pct SBL), lagged for one year as one key independent variable. The first available observation for Pct SBL is from 1995.

${ }^{2}$ More information about the SUSB is available from the website of the U.S. Census Bureau at: http://www.census.gov//econ/susb/about_the_data.html

${ }^{3}$ According to the US Small Business Administration (SBA), '... Only 4 percent of firms have more than one establishment, and they and their establishments are both described as multi-location or multi-unit.' Statistics of U.S. Businesses - Microdata and Tables, SBA/CENSUS,1998,
} 
for small businesses in our sample. For example, Hawaii in 1995 has 2.29\% more establishments than firms, the highest in our sample.

\section{[Table 1 About Here]}

We classify firms into three employment size groups: 0-4, 5-19 and 20-99. ${ }^{4}$ The size categories in the SUSB dataset changed slightly over time. Between 1995 and 2006, the Census Bureau separately reported data for firms with zero or 1-4 employee. From 2006 forward, the bureau reports data only on the combined group 0-4. We aggregate the data for the period 19952006 to maintain consistency of analysis.

The main explanatory variables of interest in our analysis are the aggregate amount of small-business lending and VC investment, which we obtain from several sources. We obtain information on bank loans to small businesses using data from the Report of Condition and Income (informally known as the "Call Report") that all insured banks are required to submit to the U.S. Federal Financial Institutions Examination Council, which collects this information on behalf of the three federal bank regulatory agencies-the Office of the Comptroller of the Currency (OCC), the Federal Reserve Board (the Fed), and the Federal Deposit Insurance Corporation (FDIC). As part of the FDIC Improvement Act of 1991, which was passed to address regulatory shortcomings identified during the last major banking crisis, banking regulators were directed (in section 122) to begin collecting annual data on lending to small

\footnotetext{
${ }^{4}$ Employment is measured in March, thus some firms (start-ups after March, closures before March, and seasonal firms) will have zero employment and some annual payroll.
} 
businesses and small farms. ${ }^{5}$ To comply with this requirement, beginning in 1993, the June Call Report includes a section that gathers information on small business lending-Schedule $R C$ - $C$ Part II: Loans to Small Businesses and Small Farms. The schedule collects information on the number and amount outstanding of loans secured by nonfarm nonresidential properties/commercial \& industrial loans with original loan amounts of less than $\$ 100,000$, with original loan amounts of $\$ 100,000$ to $\$ 250,000$ and with original loan amounts of $\$ 250,000$ to $\$ 1$ million. These are the two primary types of commercial loans made by commercial banks and correspond to items collected on Part I of Schedule RC-C, which provide the amounts of all loans secured by nonfarm nonresidential properties/commercial \& industrial loans. ${ }^{6}$ In 2009 , the decision was made to change the reporting frequency from annually to quarterly. ${ }^{7}$ Quarterly reporting of Section RC-C Part II began with the March 2010 Call Report. We also obtain from the Call Report information on the total assets of each bank and the location of each bank's headquarters. We use the information on headquarter location to categorize each bank by state. We are then able to aggregate small-business loans by state and year.

The main variable for VC investment is the total dollar value of VC deals (VCD), which we obtain from the MoneyTree Report-a joint venture between PricewaterhouseCoopers and the National Venture Capital Association using data from Thomson Reuters. The MoneyTree Report provides VC deal information at the state, regional, and national level on a quarterly basis, ${ }^{5}$ See the text of Section 122 at http://www.fdic.gov/regulations/laws/rules/8000-2400.html.

${ }^{6}$ The schedule also identifies banks that make substantially all of their business loans in original amounts less than $\$ 100,000$. There are about 1,000 such banks. For these banks, the values of business loans from Part I of Schedule RC-C are used as the values of small business loans.

7 See Notices in the Federal Register Vol. 72, No. 245 (Wednesday, December 23, 2009) at http://www.ffiec.gov/PDF/FFIEC_forms/FFIEC031_FFIEC041_20091223_ffr.pdf 
which we aggregate to the annual level. ${ }^{8}$ We considered the total number of VC deals, as well, as a robustness check, but did not find material differences. We use dollar amounts to facilitate comparison of VC deal amounts to bank loan amounts.

We draw from the existing literature a group of state-level control variables for our study, including population, growth in personal income, patent counts, education, fraction of assets held by banks with asset less than 100 million dollar, bank deposit Herfindahl-Hirschman index and public policy measures. State-level population data are from the US Census Bureau. Growth in personal income is introduced to control for demand conditions, which is in 2000 dollars, from the U.S. Bureau of Economic Analysis (BEA), part of the U.S. Department of Commerce. ${ }^{9}$ Although we recognize that not all new businesses are driven by new technology, technological advancement serves as a good base and motivation for entrepreneurial activities.

We use patent count to assess innovation. We obtain patent counts from the Patent Technology Monitoring Team (PTMT) reports, which displays the number of U.S. utility patents (i.e., "patents for invention") granted by the state of origin determined by the residence of the first-names inventor. ${ }^{10}$ Considering that it usually takes a couple of years for people to recognize technological innovation and put it into application, we count the total number of patents applied in the 20 years leading up to each analysis year as a proxy for supply of technology. ${ }^{11}$

\footnotetext{
${ }^{8}$ For more information on the MoneyTree Report, go to: https://www.pwcmoneytree.com/MTPublic/ns/index.jsp.

${ }^{9}$ For more information or to download data, visit the BEA's website at: http://www.bea.gov/regional/index.htm.

${ }^{10}$ The PTMT is part of the U.S. Patent and Trademark Office, which, itself is part of the U.S. Department of Commerce. For more information, visit PTMT's website at:

http://www.uspto.gov/products/catalog/ptmd/patent_statistics.jsp

${ }^{11}$ Alternatively, we also considered 5-year and 10-year window, which yield similar results.
} 
Evans and Leighton (1989) find that entrepreneurial activity is higher among bettereducated people. Hence, we include in our analysis the fraction of population 25 years old and over with a bachelor's degree or more from the Education Attainment data produced by the U.S. Census Bureau. ${ }^{12}$

Black and Strahan (2002) find a negative relationship between small bank market share and new incorporations. Following their methodology, we compute the fraction of bank asset held by banks with less than USD100 million in assets. Data on bank size come from the Call Report. To test whether our result is sensitive to this definition, we also look at banks with less than USD300 million assets.

Black and Strahan (2002) also show that market concentration has a negative impact on business creation. We construct a bank-deposit Herfindahl-Hirschman index (HHI) as a measure of market concentration using a modified Black and Strahan (2002) method ${ }^{13}$, which is equal to the sum of squared deposit market share across all banks operatng in a state. The HHI measure is calculated using branch-level deposit data from the FDIC's annual Summary of Deposits (SoD) Survey. ${ }^{14}$

We also include three public policy variables to capture different aspects of public policy with a potential of affecting entrepreneurship (Cumming and Li, 2013). The three policy variables are Size of Government index, measuring government transfer and subsidy, Takings

\footnotetext{
${ }^{12}$ For more information, visit the Census webpage: http://www.census.gov/hhes/socdemo/education/.

${ }^{13}$ Black and Strahan (2002) first compute HHI by Metropolitan Statistical Area (MSA). For states with more than one MSA, they average the HHI across all MSAs, weighted by total deposits in each MSA. However, the MSA flag in the FDIC's Summary of Deposits data set is missing for the period 2002 to 2008. Therefore, we simply compute the HHI at state level.

${ }^{14}$ For more information, visit the FDIC’s SoD webpage at: http://www2.fdic.gov/sod/.
} 
and Discriminatory Taxation index capturing variable tax policy, and Labor Index incorporating minimum wage, which are from the Economic Freedom of North America published by the Fraser Institute (Karabegovic and McMahon, 2008). The Fraser institution calculates the value for all three variables for each state and year. The value of each component is first calculated and then transformed into a value between zero and ten using the formula: $\left(\mathrm{V}_{\max }-\mathrm{V}_{\mathrm{i}}\right) /\left(\mathrm{V}_{\max }-\mathrm{V}_{\min }\right) * 10$, where $\mathrm{V}_{\max }$ is the largest value for the component in that year, $\mathrm{V}_{\min }$ is the smallest, and $\mathrm{V}_{\mathrm{i}}$ is the observation to be transformed. The value of a variable is an equal weighted value of its components). The indices are a relative ranking (for details, see Karabegovic and McMahon, 2008). The three public policy variables exhibit both cross-sectional and time series variation. A higher score indicates a smaller level of government intervention. ${ }^{15}$

We constructed a correlation matrix (not reported for conciseness). As expected, both bank lending and VC finance are highly correlated with each of our four dependent variables that proxy for entrepreneurship, with correlations that greater than or equal to 0.78). Bank lending and VC bank finance also are highly and positively correlated (rho $=0.64)$. Finally, many of our control variables are correlated with the dependent variables, bank lending, and VC finance. As such, in the next section, we assess bank lending and VC bank finance separately, as well as jointly, and with different sets of control variables to avoid obtaining spurious inferences arising from collinearity. Thereafter, in section 4 we consider issues of endogeneity.

\footnotetext{
${ }^{15}$ For more information or to download the data, visit the Frasier Institute's economic freedom website at: http://www.freetheworld.com/.
} 


\section{Methodology}

To estimate the relation between our four measures of entrepreneurship and our two financing measures (bank lending and VC financing), we must account for the panel nature of our data. Consequently, we estimate a panel model with year and state fixed effects.

$$
\Delta \mathrm{Y}_{i, t}=\alpha \mathbf{X}_{i, t-1}+\beta \mathrm{Y}_{t}+\delta \mathrm{S}_{i}+\eta Z_{i, t}+\varepsilon_{i, t}
$$

where:

$\Delta \mathrm{Y}_{i, t}$ is the annual growth rate in one of our four measures of entrepreneurship (number of establishements, number of firms, payroll, or employment) for state $i$ and year $t$;

$\mathbf{X}_{i, t-1}$ is a vector of financing (the annual growth rate of amount of bank lending and VC equity) for state $i$ and year $t$;

$\mathbf{Y}_{t}$ is a vector of dummy variables for year $t$;

$\underline{\mathbf{S}}_{i}$ is a vector of dummy variables for state $i$;

$\underline{\mathbf{Z}}_{i, t}$ is a vector of state-level control variables (Personal Income, Education, Patents, HHI, Size of Government, Taxation, Labor Freedom, number of business incubator, number of small business, academic $R \& D$, difference between corporate tax and income tax); and $\varepsilon_{i, t}$ is a random error term for state $i$ and year $t$.

We use growth rates on both the left-hand-side and the right-hand-side. We also measure each of our four dependent variables for three different firm size buckets: 0-4, 5-19 and 20-99.

In section 5, we consider instrumental variable regression estimates. We discuss the methods used in that section. 


\section{Ordinary Panel Data Estimates}

Ordinary panel data estimates (without corrections for endogeneity) are presented in Tables 2 and 3. Each table comprises regressions for growth rate in the number of firms, establishments, employment, and payroll. Table 2 provides simple estimates with only Pct SBL or Pct VCD as separate explanatory variables (along with a constant, not reported in the table for conciseness). Table 3 includes both Pct SBL and Pct VCD together as explanatory variables in the same regression with a number of different control variables. Our results are robust to clustering by state or year; additional results are available on request.

[Tables 2-4 About Here]

Table 2 presents 8 regression models for the percentage changes in firms, establishments, employment, and payroll. Two regressions are presented to separately show simple regressions for inclusion of Pct SBL and Pct VCD separately. (These regressions are akin to show comparison of means tests.) The regressions in Table 2 highlight the central features of the data, which remain quite robust in all of the subsequent tables. Generally, VC investment tends to be positively and significantly related to growth in firms and establishments for firm size 5-19 employees, and positively related to firm and payroll for firms with 20-99 employees. Bank finance is unrelated to growth of firms or establishments of any size. 
Specifically, Table 2 shows that Pct VCD is positive related to the growth of firms and establishments with 5-19 employers, and these effects are significant at the $10 \%$ and 5\% level, respectively. The economic significance is large. These coefficients imply that, for a onestandard-deviation change in Pct VCD, there is an increase in the growth rate in firms and establishments by approximately $38.3 \%$ and $50.0 \%$, respectively, relative to their mean values (shown in Table 1). For firms with 20-99 employees, an increase in Pct VCD by one-standard deviation increases the firm growth rate and total payroll growth rate by $18.5 \%$ and $4.8 \%$, respectively, relative to the mean growth rate of these variables. VCD is unrelated to growth among firms with 0-4 employees.

Unlike the effect of VC, in Table 2 Pct SBL is insignificant for firms, establishments, employment and payroll, and even negative for firms with 0-4 employees. In other words, the data suggest higher levels of bank finance and periodic charges on such finance give rise to capital constraints that discourage employment growth among smaller firms with fewer than 5 employees.

Table 3 shows similar regressions as in Table 2, but with some added control variables and both VCD and SBL in the same regressions. In Table 3 we show the inclusion of controls for income, education, patents and public policy indices do not affect the results in Table 2. In many cases, the results in Table 3 show the same statistical significance but a slightly greater economic significance for VCD. As well, SBL is insignificant or negative and significant as it was in Table 2. Also, we show in Models (2), (4), (6) and (8) the results when the year 2000 is excluded from the data; this exclusion is reported since 2000 was an outlier year for VC due to the Internet bubble. Again, our findings are extremely robust and do not change any of the inferences reported in Table 2, the effect of VCD in some regressions is even stronger 
The control variables in Table 3 generally show that growth in firms, establishments, employment, and payroll is associated with growth in personal income. We interpret this effect in two ways: (1) greater personal in a region enables more individuals to take risk and become entrepreneurs, and (2) greater personal wealth in a region is associated with more angel investors; however, our data do not enable us to distinguish between these alternative interpretations. Also, we find evidence that growth in new firms and establishments is associated with higher levels of education, fewer labor restrictions, and more SBIR awards. These latter findings are consistent with Cumming and Li (2013). We see some evidence in Table 3 that patents are negatively associated with the different growth measures. One explanation is that the monopoly created by patents impedes growth. However, this evidence is not completely robust. Further research is warranted.

In our specifications herein, we find that, regardless of which controls for governmental or other variables we include, our findings for the effect of VC investments and bank lending do not materially change. We include personal income to control for economic conditions (as in Black and Strahan, 2002), and find it is positively significant. Likewise, when we include other variables in the specifications, such as population or growth in personal income, the estimates pertaining to bank lending and VC investment are qualitatively unchanged. Alternative specifications are available on request. 


\section{Two-step IV estimates}

Although results from our fixed-effect regressions shown in Tables 2-3 support the idea that VC investment motivates entrepreneurial activities, they are nevertheless subject to endogeneity or reverse causality concerns due to the fact that VC investment may be endogenous with entrepreneurial growth. For example, instead of VC investment facilities business creation, it is likely that VCs select a region where there are historically more entrepreneurial activities. Another possibility is that both VCs and entrepreneurs choose to locate their offices in a region that offers better business opportunities and environment. We address this concern using an instrumental variable, which is a modified version of the one proposed by Samila and Sorenson (2011). The idea here is that VC supply relies on the demand for alternative assets by limited partners. Institutional investors generally adopt certain investing strategy, which includes maintaining an optimal allocation of assets across classes. Endowment funds need to allocate more assets to VCs to maintain asset allocations in the case of higher return. As a result, the supply of VC funds correlate highly with lagged endowment returns. On the other hand, endowment funds rarely invest directly in start-ups, so their returns should have no direct impact on entrepreneurship. Samila and Sorenson (2011) use a 3-year measure of returns. Here, we use a 1-year measure, due to the fact that the 3-year measure does not enable one to appropriately distinguish the financial crisis period and over-averages returns across time during that period. Distance weighting is used to account for the fact that limited partners (LPs) tend to invest in funds headquartered near them. ${ }^{16}$ The IV variable is computed as follows:

\footnotetext{
${ }^{16}$ See Samila and Sorenson (2011) for a detailed discussion of the instrumental variable. We thank Sampsa Samila for providing data on endowment fund returns.
} 


$$
\text { LP returns }_{\mathrm{i}, \mathrm{t}}=\sum_{j} \frac{E R_{t-1} \operatorname{In}\left(1+L P_{t-10, j}\right)}{1+\text { dist }_{\mathrm{i}, \mathrm{j}}}
$$

where $E R_{t-1}$ is the average returns to college endowments in $t-1$ year, $\ln \left(1+L P_{t-10, j}\right)$ denotes the logged count of limited partners located in state $\mathrm{j}$ who had invested in any private equity fund for at least 10 years prior to the start of their sample period, and dist $t_{i j}$ denotes the distance in miles between the capital cities of state $i$ and state $j$. Data on the number of LPs are obtained from VentureXpert. We next regress the growth rate of VC on the instrumental variable and logarithm of population. The predicted value (Pct VCD hat) is used to to infer the growth rate of total VC supply.

To disentangle the small-business loan demand and supply effects, we regress the logarithm of one plus state-level total small-business loans on ratio of bank capital to assets, bank-deposit HHI, fraction of state-level bank assets held by banks with assets less than 100 million dollars and the fraction of state-level bank assets held by banks with assets less than 300 million dollars. The predicted value is used to infer the growth rate of total small bank loan which is used as an instrumental variable for small-business loan supply. Data on bank asset, equity and deposits are from the FFIEC Call Report.

The measure of total small-business lending is also subject to endogeneity concerns. The total bank lending to small businesses reflects not only supply of bank credit, but also loan demand by small businesses. It is possible that increased access to loans helps small businesses to grow. An alternative explanation is that a larger number of small businesses increases demand for small-business loans. To address this potential issue, we construct an instrumental variable for small-business loan supply based on the banking literature. Frame, Srinivasan and Woosley (2001) finds that bank assets help to predict small business lending. Kishan and Opieal (2000) 
suggest that bank capital (total equity to total asset ratio) and bank size are important determinants of loan supply using U.S. data. Ivashina and Scharfstein (2010) demonstrate that larger ratios of deposits to assets are related to higher bank loan supply.

We considered correlation coefficients between the instruments, potentially endogenous variables, and the four main dependent variables of interest. Generally, the instruments are much more closely correlated with the potentially endogenous variable than they are correlated with the four main dependent variables. Since these instruments seem to work reasonably well for the data, and because they were used in prior work on topic in the VC and banking literature, we use these instruments in our first-stage regressions.

To disentangle the small-business loan demand and supply effects, we regress the logarithm of one plus state-level total small-business loans on ratio of bank capital to assets, bank-deposit HHI, fraction of state-level bank assets held by banks with assets less than 100 million dollars and the fraction of state-level bank assets held by banks with assets less than 300 million dollars, and year and state dummies. The predicted value (Pct SBL hat) is used to infer the growth rate of total small bank loan which is used as an instrumental variable for smallbusiness loan supply Data on bank asset, equity and deposits are from the FFIEC Call Report.

The regressions are reported in Table 4. Panel A indicates that LP returns are positively related to VC investment. Panel B indicates $\mathrm{HHI}$ is negatively related to bank loans, and pct assets $300 \mathrm{M}$ is also negatively related to bank loans. The second step regressions (discussed below) are robust to alternative specifications of these first step regressions.

[Table 4 About Here] 
The second step instrumental variable regressions are reported in Tables 5 . Tables 5 is similar to Table 3 in terms of the included control variables, and the exclusion of year 2000 in Models (2), (4), (6) and (8). As discussed below, the findings are quite robust regardless of which control variables are included.

[Tables 5 About Here]

Table 5 Panel A shows that the effect of Pct VCD hat is not significant among firms with 0-4 employees. The effect of VCD on all four dependent variables is positively and significantly for firms with 5-19 employees, as shown in Table 5 Panel B. And these effects are significant at at least the 5\% level. A $10 \%$ increase in Pct VCD hat gives rise to an increase in firms, establishments, employment, and payroll by 2.6\%, 2.3\%, 2.9\%, and 3.9\%, respectively. Also, for firms with 20-99 employees, Panel C shows that a 10\% increase in Pct VCD hat gives rise to a $1.9 \%$ increase in firms, although this effect is significant at the $10 \%$ level in Models (1) but not (2). Also, VCD is significantly related to payroll growth for firms with $20-99$ employees at the $1 \%$ level whereby a $10 \%$ increase in VCD gives rise to a $5.9 \%$ increase in payroll. The effect of VCD on establishments and employment is insignificant in Models (3) - (6) in Panel C for firms with 20-99 employees. We do not have a good explanation for these insignificant latter results, other than the notion that VC matters less as firms become larger.

Table 5 Panels A and B shows an insignificant effect of bank finance on each of the growth measures for firms with 0-4 and 5-19 employees. For firms with 20-99 employees, there 
is some evidence that banks impact growth in establishments and payroll. However, these estimates are only significant at the $10 \%$ level, and not robust to the use of instruments (see Table 3).

The estimates for the control variables in Table 5 are similar to those reported in Table 3. Smaller governments, labor freedom and SBIR awards encourage entrepreneurial growth. The inclusion or exclusion of other control variables is immaterial to the findings for the effect of banks versus VC. Alternative specifications are available on request.

Overall, the main finding from the regressions with the controls for endogeneity is that VC has a more pronounced impact on entrepreneurship and growth than banks, particularly for firms with 5-19 employees. Without implementing controls for endogeneity, the effect of VCs on entrepreneurship was still more pronounced and robust than the effect of banks.

\section{Additional Robustness Checks}

The FFIEC Call Report provides information on small-business loans for the consolidated bank, which may have branches in many states or nationwide, but only provides information on the location of its headquarters. For a multi-state bank such as Bank of America, which operates nationwide, the amount of small-business loans reported on the Call Report is the sum of small-business loan granted by all branches in all states where it operates in. So, for example, if a bank with headquarters in state A operates five branches in state A and six

branches in state B, the total amount of small-business loans reported for the bank in state A will 
be equal to total amount of small-business loans granted by all of the 11 branches; the reported amount of small-business lending in state B will be zero.

To address this FFIEC reporting issue, we make use of branch-level data from the FDIC's Summary of Deposits survey. We estimate the local small-business loans for multi-state banks by assuming that local small-business loans are made in proportion to the branch-level deposits in each state where the bank operates. We first compute the fraction of deposits in each state using the amount branch-level deposits for each bank in each state, and then use these ratios to allocate the bank's loans as reported on the Call Report to each state; we then use this adjusted loan data in the regression analyses.

In addition, we also repeat the analysis using other instrumental variables for bank smallbusiness loan supply. The instrumental variables include the number of banks with adjusted capital ratio less than $8 \%$, the percentage of state-wide assets held by undercapitalized banks, defined as bank with adjusted capital ratio less than $8 \%$, average bank age and, last, total assets. Regardless of which method we used to test for the effect of banks, we are unable to generate estimates that increase the importance of banks relative to VC for entrepreneurship and growth. 


\section{Conclusion}

In this paper we empirically compared for the first time the effect of bank lending versus VC investment on entrepreneurial growth in the U.S. across 50 states over the years 1995-2011. The data indicate that VCs significantly influence growth of firms, establishments, employment, and payroll.

Our findings are consistent with the literature that VCs are important for entrepreneurship and growth, particularly for firms with 5-19 employees. We observe some evidence, although not robust and only with the use of instrumental variables, of a positive effect of banks on growth among firms with 20-99 employees. Most entrepreneurs seek bank finance, and bank finance is the most commonly used form of finance for entrepreneurs. Entrepreneurs, however, are particularly engaged by VCs in terms of the investor's value-added activities regarding financial, administrative, human resource, and marketing advice, and have a network of contacts with investment banks, consultants, legal and accounting service providers, among other things, that they can bring in to help entrepreneurs. VC investors encourage employment in start-up firms and more quickly bring about stock option plans and compensation schemes in start-ups, thereby facilitating the entrepreneurial process. To this end, our data are consistent with the view that regional areas with a significant VC presence more quickly enable entrepreneurial agglomeration. Since bank investors are on average more passive than VC investors, the impact of banks on entrepreneurship is not as pronounced as the impact of VC on entrepreneurship. 


\section{References}

Audretsch, D., 2007a. “Entrepreneurship Capital and Economic Growth.” Oxford Review of Economic Policy, 23, 63-78.

Audretsch, D., 2007b. The Entrepreneurial Society, Oxford: Oxford University Press.

Audretsch, D., and M. Keilbach, 2007. "The Localisation of Entrepreneurship Capital: Evidence from Germany.” Regional Science, 86, 351-365.

Bates, T., and W. D. Bradford, 2008. "Venture-Capital Investments in Minority Business" Journal of Money, Credit and Banking 40, 489-504.

Berger, A.N., and L.K. Black, 2011. "Bank Size, Lending Technologies, and Small Business Finance.” Journal of Banking and Finance, 35, 724-735.

Berger, A.N., and K. Schaeck, 2011. “Small and Medium-Sized Enterprises, Bank Relationship Strength, and the Use of Venture Capital.” Journal of Money, Credit, and Banking 43, 461-490.

Bertoni, F., M.G. Colombo, and L. Grilli, 2011. "Venture Capital Financing and the Growth of High-tech Start-ups: Disentangling Treatment from Selection Effects.” Research Policy 40, 1028-1043.

Black, S.E. and P.E. Strahan, 2002. “Entrepreneurship and Bank Credit Availability.” Journal of Finance, 57, 2807-2833.

Chavis, L.W., L.F. Klapper, and I. Love, 2009. "The Impact of the Business Environment on Young Firm Financing.” World Bank Economic Review 25(3), 486-507.

Cosh, A., D.J. Cumming, and A. Hughes, 2009. “Outside Entrepreneurial Capital.” Economic Journal 119, 1494-1533.

Cumming, D.J., and D. Li, 2013. "Public Policy, Entrepreneurship, and Venture Capital in the United States” Journal of Corporate Finance 23, 345-367.

DeYoung, R., 2009. "Banking in the United States.” In Allen N. Berger, Philip Molyneux, and John O. Wilson (eds.). Oxford Handbook of Banking, Oxford University Press.

Engel, D., and M. Keilbach, 2006. "Firm-Level Implications of Early Stage Venture Capital Investment - An Empirical Investigation.” Journal of Empirical Finance 14, 150-167.

Evans, D.S., and L.S. Leighton, 1989. “Some Empirical Aspects of Entrepreneurship.” American Economic Review, 519-535. 
Frame, W. S., A. Srinivasan, and L. Woosley, 2001. "The Effect of Credit Scoring on SmallBusiness Lending.” Journal of Money, Credit, and Banking 33, 813-825.

Gompers, P., and J. Lerner, 1999. The Venture Capital Cycle. Cambridge: MIT Press.

Hirukawa, M. and M. Ueda, 2008. “Venture Capital and Innovation: Which is First?” CEPR Discussion Paper 7090.

Ivashina, V and D. Scharfstein, 2010. "Bank Lending During the Financial Crisis of 2008." Journal of Financial Economics 97, 319-338.

Karabegovic, A., and F. McMahon, 2008. Economic Freedom in North America. Vancouver: The Fraser Institute.

Keuschnigg, C., 2004. “Venture Capital Backed Growth.” Journal of Economic Growth 9, 239261.

Keuschnigg, C., and S.B. Nielsen, 2001. Public Policy for Venture Capital.” International Tax and Public Finance 8, 557-572.

Keuschnigg, C., and S.B. Nielsen, 2003a. “Tax Policy, Venture Capital, and Entrepreneurship.” Journal of Public Economics 87, 175-203.

Keuschnigg, C., and S.B. Nielsen, 2003b. “Taxes and Venture Capital Support.” Review of Finance 7, 515-539.

Keuschnigg, C., and S.B. Nielsen, 2004a. "Progressive Taxation, Moral Hazard, and Entrepreneurship.” Journal of Public Economic Theory 6, 471-490.

Keuschnigg, C., and S.B. Nielsen, 2004b. "Start-ups, Venture Capitalists and the Capital Gains Tax.” Journal of Public Economics, 88, 1011-1042.

Keuschnigg, C., and S.B. Nielsen, 2004c. "Public Policy for Start-up Entrepreneurship with Venture Capital and Bank Finance.” Working Paper, University of St. Gallen and Copenhagen Business School.

Klapper, L., L. Laeven, and R. Rajan, 2006. "Entry Regulation as a Barrier to Entrepreneurship,” Journal of Financial Economics 82, 591-629.

Kishan, R. P. and T. P. Opieal, 2000. "Bank Size, Bank Capital and the Bank Lending Channel.” Journal of Money, Credit and Banking 32, 121-141.

Levine, R., 2005. "Finance and Growth: Theory and Evidence." Handbook of Economic Growth, in: Philippe Aghion \& Steven Durlauf (ed.), Handbook of Economic Growth, edition 1, volume 1 , chapter 12, pages 865-934 Elsevier. 
Robb, A., and D. Robinson, 2014. "The Capital Structure Decisions of New Firms," Review of Financial Studies 27, 153-179.

Rousseau, P.L., and P. Wachtel, 2000. "Equity Markets and Growth: Cross-Country Evidence on Timing and Outcomes.” 1980-1995” Journal of Banking and Finance 24, 1933-1957.

Samila, S. and O. Sorenson, 2009. "Venture Capital, Entrepreneurship, and Regional Economic Growth.” Review of Economics and Statistics, 93, 338-349.

Wang, L., and S. Wang, 2012. "Economic Freedom and Cross-Border Venture Capital Performance.” Journal of Empirical Finance 19, 26-50

World Bank, 2004. World Bank Group Support for Small Business. Washington, DC: World Bank.

Yung, C., 2009. "Entrepreneurial Financing and Costly Due Diligence.” Financial Review, 44: 137-149. 


\section{Table 1: Variable definitions, sources and summary statistics}

Panel A presents definitions, sources and statistics for all dependent variables used in the study. Definitions, sources and statistics for all independent variables are presented in Panel B. The sample consists of a balanced panel data on 50 U.S. states for the period 1992-2011. The sample is separated into three size types by employment size: 0-4, 5-19 and 20-99 employees.

\section{Panel A. Dependent Variables}

\begin{tabular}{|c|c|c|c|c|c|c|}
\hline $\begin{array}{l}\text { Firm } \\
\text { size } \\
\text { catego } \\
\text { ry }\end{array}$ & Variable & Definition & $\mathrm{N}$ & $\begin{array}{c}\text { Mea } \\
\mathrm{n}\end{array}$ & $\begin{array}{l}\text { Std } \\
\text { Dev }\end{array}$ & $\begin{array}{c}\text { Media } \\
\mathrm{n}\end{array}$ \\
\hline \multirow[t]{4}{*}{$0-4$} & Pct Firms & Growth rate of number of firms (\%) & $\begin{array}{c}85 \\
0\end{array}$ & $\begin{array}{c}0.45 \\
7\end{array}$ & 1.906 & 0.455 \\
\hline & $\begin{array}{c}\text { Pct } \\
\text { Establishments }\end{array}$ & Growth rate of number of establishments (\%) & $\begin{array}{c}85 \\
0\end{array}$ & $\begin{array}{c}0.45 \\
4\end{array}$ & 1.896 & 0.465 \\
\hline & $\begin{array}{l}\text { Pct } \\
\text { Employment }\end{array}$ & Growth rate of number of employees (\%) & $\begin{array}{c}85 \\
0\end{array}$ & $\begin{array}{c}0.51 \\
7\end{array}$ & 1.982 & 0.488 \\
\hline & Pct Payroll & $\begin{array}{l}\text { Growth rate of total payroll in thousands of } \\
\text { dollars (\%) }\end{array}$ & $\begin{array}{c}85 \\
0\end{array}$ & $\begin{array}{c}3.40 \\
0\end{array}$ & 4.269 & 3.415 \\
\hline \multirow[t]{4}{*}{$5-19$} & Pct Firms & Growth rate of number of firms (\%) & $\begin{array}{c}85 \\
0\end{array}$ & $\begin{array}{c}0.24 \\
0\end{array}$ & 2.004 & 0.396 \\
\hline & $\begin{array}{l}\text { Pct } \\
\text { Establishments }\end{array}$ & Growth rate of number of establishments (\%) & $\begin{array}{c}85 \\
0\end{array}$ & $\begin{array}{c}0.18 \\
4\end{array}$ & 1.940 & 0.290 \\
\hline & $\begin{array}{c}\text { Pct } \\
\text { Employment }\end{array}$ & Growth rate of number of employees (\%) & $\begin{array}{c}85 \\
0\end{array}$ & $\begin{array}{c}0.28 \\
0\end{array}$ & 2.297 & 0.545 \\
\hline & Pct Payroll & $\begin{array}{l}\text { Growth rate of total payroll in thousands of } \\
\text { dollars (\%) }\end{array}$ & $\begin{array}{c}85 \\
0\end{array}$ & $\begin{array}{c}0.77 \\
7\end{array}$ & 2.757 & 0.944 \\
\hline \multirow[t]{4}{*}{$20-99$} & Pct Firms & Growth rate of number of firms (\%) & $\begin{array}{c}85 \\
0\end{array}$ & $\begin{array}{c}0.49 \\
8\end{array}$ & 2.791 & 0.694 \\
\hline & $\begin{array}{l}\text { Pct } \\
\text { Establishments }\end{array}$ & Growth rate of number of establishments (\%) & $\begin{array}{c}85 \\
0\end{array}$ & $\begin{array}{c}0.39 \\
1\end{array}$ & 3.360 & -0.008 \\
\hline & $\begin{array}{c}\text { Pct } \\
\text { Employment }\end{array}$ & Growth rate of number of employees (\%) & $\begin{array}{c}85 \\
0\end{array}$ & $\begin{array}{c}0.53 \\
7\end{array}$ & 3.116 & 1.016 \\
\hline & Pct Payroll & $\begin{array}{l}\text { Growth rate of total payroll in thousands of } \\
\text { dollars (\%) }\end{array}$ & $\begin{array}{c}85 \\
0\end{array}$ & $\begin{array}{c}3.84 \\
1\end{array}$ & 4.024 & 4.440 \\
\hline
\end{tabular}


Panel B. Explanatory Variables

\begin{tabular}{|c|c|c|c|c|c|}
\hline Variable & Definition & $\mathrm{N}$ & Mean & $\begin{array}{l}\text { Std } \\
\text { Dev }\end{array}$ & Median \\
\hline Pct SBL & Growth rate of total small bank loan in year t-1 & 850 & 0.0167 & 0.145 & 0.010 \\
\hline Pct VCD & Growth rate of total venture capital investment in year t-1 & 778 & 4.642 & 30.672 & 0.148 \\
\hline Pct. Personal Income & Growth rate of personal income in year t-1 & 850 & 0.050 & 0.031 & 0.053 \\
\hline Education & $\begin{array}{l}\text { Fraction of persons } 25 \text { years old and over with a } \\
\text { bachelor's degree or more }\end{array}$ & 850 & 0.257 & 0.049 & 0.253 \\
\hline Log(Patent 20yr) & $\begin{array}{l}\text { Logarithm of cumulative patent counts during the } 20 \text { - } \\
\text { year period from t- } 20 \text { to t- } 1 \text { year }\end{array}$ & 850 & 9.207 & 1.368 & 9.241 \\
\hline $\begin{array}{l}\text { Size of Government } \\
\text { Index }\end{array}$ & $\begin{array}{l}\text { Computed by the Fraser Institute, the index measures the } \\
\text { government intervention in the economy, The index has a } \\
\text { scale from } 0 \text { to } 10 \text {, with a high score indicating a smaller } \\
\text { government sector. }\end{array}$ & 850 & 6.946 & 1.022 & 7.100 \\
\hline $\begin{array}{l}\text { Takings and Dis. } \\
\text { Tax Index }\end{array}$ & $\begin{array}{l}\text { Computed by the Fraser Institute, the index measures the } \\
\text { general tax revenues collected by government. The index } \\
\text { has a scale from } 0 \text { to } 10 \text {, with a higher score indicating a } \\
\text { lower degree of takings and discriminatory taxation. }\end{array}$ & 850 & 6.223 & 0.632 & 6.200 \\
\hline $\begin{array}{l}\text { Labor Freedom } \\
\text { Index }\end{array}$ & $\begin{array}{l}\text { Computed by the Fraser Institute, the index measures the } \\
\text { general labor conditions. The index has a scale from } 0 \text { to } \\
\text { 10, with a higher score indicating a lower level of labor } \\
\text { regulation. }\end{array}$ & 850 & 7.144 & 0.527 & 7.200 \\
\hline Lag NBIA/Pop & $\begin{array}{l}\text { Number of business incubators per } 1 \text { million people in } \\
\text { year t-1 }\end{array}$ & 850 & 0.522 & 0.386 & 0.548 \\
\hline Lag SBIR/Pop & $\begin{array}{l}\text { Number of Small Business Innovation Research Awards } \\
\text { per } 1 \text { million people in year t- } 1\end{array}$ & 850 & 2.187 & 1.188 & 2.266 \\
\hline Lag Academic R\&D & $\begin{array}{l}\text { Academic science and engineering R\&D per } \$ 1,000 \text { of } \\
\text { GDP }\end{array}$ & 850 & 12.836 & 1.118 & 12.934 \\
\hline $\begin{array}{l}\text { Corporate - Income } \\
\text { Taxes }\end{array}$ & $\begin{array}{l}\text { The difference between corporate and individual top } \\
\text { marginal income tax rate }\end{array}$ & 850 & 0.416 & 0.028 & 0.420 \\
\hline
\end{tabular}




\section{Table 2: Base Model Regression}

The table shows the coefficient estimates from ordinary least square (OLS) regressions across firm size category for the growth rate of number of firms in column (1) and (2), growth rate of number of establishments in column (3) and (4), growth rate of number of employees in column (5) and (6), and growth rate of number of payroll in thousands of dollars in column (7) and (8). All variables are defined in Table 1. The sample is 50 US states between 1992 and 2011. All regressions include controls for year and state fixed effects. Standard errors are in parentheses. ***, **, and $*$ denote significance at the $1 \%$, $5 \%$ and $10 \%$ level, respectively.

\begin{tabular}{|c|c|c|c|c|c|c|c|c|c|}
\hline \multirow{2}{*}{$\begin{array}{c}\text { Firm } \\
\text { size } \\
\text { category }\end{array}$} & & \multicolumn{2}{|c|}{ Pct Firms } & \multicolumn{2}{|c|}{ Pct Establishment } & \multicolumn{2}{|c|}{ Pct Employment } & \multicolumn{2}{|c|}{ Pct Payroll } \\
\hline & & $(\mathbf{1})$ & (2) & (3) & (4) & (5) & (6) & (7) & (8) \\
\hline \multirow[t]{6}{*}{$0-4$} & Pct SBL & -0.221 & & -0.227 & & -0.143 & & -0.363 & \\
\hline & & $(0.282)$ & & $(0.282)$ & & $(0.363)$ & & $(0.848)$ & \\
\hline & Pct VCD & & -0.001 & & -0.001 & & 0.000 & & 0.002 \\
\hline & & & $(0.001)$ & & $(0.001)$ & & $(0.002)$ & & $(0.004)$ \\
\hline & $\mathrm{N}$ & 850 & 850 & 850 & 850 & 850 & 850 & 850 & 850 \\
\hline & R-square & 0.614 & 0.649 & 0.610 & 0.647 & 0.454 & 0.474 & 0.422 & 0.425 \\
\hline \multirow[t]{6}{*}{$5-19$} & Pct SBL & 0.058 & & 0.054 & & -0.086 & & 0.183 & \\
\hline & & $(0.302)$ & & $(0.298)$ & & $(0.400)$ & & $(0.451)$ & \\
\hline & Pct VCD & & $0.003^{*}$ & & $0.003 * *$ & & 0.000 & & 0.000 \\
\hline & & & $(0.001)$ & & $(0.001)$ & & $(0.002)$ & & $(0.002)$ \\
\hline & $\mathrm{N}$ & 850 & 850 & 850 & 850 & 850 & 850 & 850 & 850 \\
\hline & R-square & 0.661 & 0.668 & 0.646 & 0.649 & 0.558 & 0.568 & 0.603 & 0.639 \\
\hline \multirow[t]{6}{*}{$20-99$} & Pct SBL & 0.397 & & 0.404 & & 0.197 & & 0.086 & \\
\hline & & $(0.439)$ & & $(0.450)$ & & $(0.472)$ & & $(0.581)$ & \\
\hline & Pct VCD & & $0.003^{*}$ & & 0.002 & & 0.003 & & $0.006^{* *}$ \\
\hline & & & $(0.002)$ & & $(0.002)$ & & $(0.002)$ & & $(0.003)$ \\
\hline & $\mathrm{N}$ & 850 & 850 & 850 & 850 & 850 & 850 & 850 & 850 \\
\hline & R-square & 0.645 & 0.667 & 0.746 & 0.760 & 0.672 & 0.697 & 0.701 & 0.738 \\
\hline
\end{tabular}


Table 3. Venture Capital and Bank Variables Included Together

The table shows the coefficient estimates from ordinary least square (OLS) regressions across firm size category for the growth rate of number of firms in column (1) and (2), growth rate of number of establishments in column (3) and (4), growth rate of number of employees in column (5) and (6), and growth rate of number of payroll in thousands of dollars in column (7) and (8). All variables are defined in Table 1. The full sample is 50 U.S. states between 1995 and 2011. Model (1), (3), (5) and (7) are based the full sample, while model (2), (4), (6) and (8) exclude the year 2000. All regressions include controls for year and state fixed effects. Standard errors are in parentheses. ${ }^{* *},{ }^{* *}$, and ${ }^{*}$ denotes significance at the $1 \%, 5 \%$ and $10 \%$ level, respectively.

\begin{tabular}{|c|c|c|c|c|c|c|c|c|c|}
\hline \multirow{2}{*}{$\begin{array}{l}\text { Firm size } \\
\text { category }\end{array}$} & & \multicolumn{2}{|c|}{ Pct Firms } & \multicolumn{2}{|c|}{ Pct Establishment } & \multicolumn{2}{|c|}{ Pct Employment } & \multicolumn{2}{|c|}{ Pct Payroll } \\
\hline & & (1) & (2) & (3) & (4) & (5) & (6) & (7) & (8) \\
\hline \multirow[t]{16}{*}{$0-4$} & Pct SBL & $\begin{array}{l}-0.467 \\
(0.298)\end{array}$ & $\begin{array}{c}-0.441 \\
(0.306)\end{array}$ & $\begin{array}{c}-0.472 \\
(0.296)\end{array}$ & $\begin{array}{l}-0.448 \\
(0.303)\end{array}$ & $\begin{array}{l}-0.473 \\
(0.406)\end{array}$ & $\begin{array}{l}-0.413 \\
(0.401)\end{array}$ & $\begin{array}{c}-0.581 \\
(0.762)\end{array}$ & $\begin{array}{l}-0.743 \\
(0.781)\end{array}$ \\
\hline & Pct VCD & -0.001 & -0.001 & -0.001 & -0.001 & 0.000 & 0.000 & 0.000 & -0.001 \\
\hline & & $(0.001)$ & $(0.001)$ & $(0.001)$ & $(0.001)$ & $(0.002)$ & $(0.002)$ & $(0.008)$ & $(0.007)$ \\
\hline & Pct Personal Income & $\begin{array}{c}15.3^{* * *} \\
(3.329)\end{array}$ & $\begin{array}{c}15.157 * * * \\
(3.442)\end{array}$ & $\begin{array}{c}15.346 * * * \\
(3.299)\end{array}$ & $\begin{array}{c}15.203 * * * \\
(3.413)\end{array}$ & $\begin{array}{c}17.598 * * * \\
(3.441)\end{array}$ & $\begin{array}{c}16.644 * * * \\
(4.033)\end{array}$ & $\begin{array}{c}25.031^{* * *} \\
(7.050)\end{array}$ & $\begin{array}{c}22.59 * * * \\
(7.637)\end{array}$ \\
\hline & Education & $\begin{array}{l}5.843^{*} \\
(3.332)\end{array}$ & $\begin{array}{l}5.967 * \\
(3.372)\end{array}$ & $\begin{array}{l}5.894^{*} \\
(3.337)\end{array}$ & $\begin{array}{l}5.979^{*} \\
(3.367)\end{array}$ & $\begin{array}{c}8.378 \\
(5.389)\end{array}$ & $\begin{array}{c}8.904 \\
(5.899)\end{array}$ & $\begin{array}{l}-10.836 \\
(11.071)\end{array}$ & $\begin{array}{l}-12.260 \\
(11.492)\end{array}$ \\
\hline & Log(Patent 20yr) & $\begin{array}{c}-0.816^{* *} \\
(0.390)\end{array}$ & $\begin{array}{c}-0.921^{* *} \\
(0.390)\end{array}$ & $\begin{array}{c}-0.831^{* *} \\
(0.386)\end{array}$ & $\begin{array}{c}-0.939 * * \\
(0.385)\end{array}$ & $\begin{array}{l}-0.582 \\
(0.450)\end{array}$ & $\begin{array}{c}-0.646 \\
(0.474)\end{array}$ & $\begin{array}{c}-1.813^{* *} \\
(0.692)\end{array}$ & $\begin{array}{c}-2.242 * * * \\
(0.535)\end{array}$ \\
\hline & Homestead Exemption & $\begin{array}{l}-0.017 \\
(0.043)\end{array}$ & $\begin{array}{c}-0.016 \\
(0.043)\end{array}$ & $\begin{array}{c}-0.016 \\
(0.042)\end{array}$ & $\begin{array}{c}-0.014 \\
(0.043)\end{array}$ & $\begin{array}{c}0.004 \\
(0.049)\end{array}$ & $\begin{array}{c}0.005 \\
(0.051)\end{array}$ & $\begin{array}{l}-0.014 \\
(0.059)\end{array}$ & $\begin{array}{l}-0.013 \\
(0.058)\end{array}$ \\
\hline & Size of Government Index & $\begin{array}{c}0.231 \\
(0.206)\end{array}$ & $\begin{array}{c}0.241 \\
(0.201)\end{array}$ & $\begin{array}{c}0.228 \\
(0.205)\end{array}$ & $\begin{array}{c}0.238 \\
(0.199)\end{array}$ & $\begin{array}{c}0.621^{* * *} \\
(0.230)\end{array}$ & $\begin{array}{c}0.586^{* *} \\
(0.241)\end{array}$ & $\begin{array}{l}-0.400 \\
(0.692)\end{array}$ & $\begin{array}{l}-0.324 \\
(0.721)\end{array}$ \\
\hline & Takings and Dis. Tax Index & $\begin{array}{l}-0.086 \\
(0.276)\end{array}$ & $\begin{array}{l}-0.062 \\
(0.281)\end{array}$ & $\begin{array}{l}-0.099 \\
(0.277)\end{array}$ & $\begin{array}{l}-0.073 \\
(0.282)\end{array}$ & $\begin{array}{l}-0.440 \\
(0.347)\end{array}$ & $\begin{array}{l}-0.306 \\
(0.366)\end{array}$ & $\begin{array}{l}-0.084 \\
(0.601)\end{array}$ & $\begin{array}{c}0.029 \\
(0.569)\end{array}$ \\
\hline & Labor Freedom Index & $\begin{array}{c}0.947 * * \\
(0.379)\end{array}$ & $\begin{array}{c}0.928^{* *} \\
(0.389)\end{array}$ & $\begin{array}{l}0.93 * * \\
(0.380)\end{array}$ & $\begin{array}{c}0.908^{* *} \\
(0.391)\end{array}$ & $\begin{array}{c}0.403 \\
(0.364)\end{array}$ & $\begin{array}{c}0.366 \\
(0.400)\end{array}$ & $\begin{array}{l}1.772^{*} \\
(0.950)\end{array}$ & $\begin{array}{c}1.161 \\
(1.001)\end{array}$ \\
\hline & Lag NBIA/Pop & $\begin{array}{c}0.53^{*} \\
(0.275)\end{array}$ & $\begin{array}{l}0.553^{*} \\
(0.293)\end{array}$ & $\begin{array}{l}0.541^{*} \\
(0.281)\end{array}$ & $\begin{array}{l}0.569^{*} \\
(0.299)\end{array}$ & $\begin{array}{c}0.382 \\
(0.298)\end{array}$ & $\begin{array}{c}0.405 \\
(0.348)\end{array}$ & $\begin{array}{c}0.371 \\
(0.732)\end{array}$ & $\begin{array}{c}0.917 \\
(0.678)\end{array}$ \\
\hline & Lag SBIR/Pop & $\begin{array}{c}0.245^{* *} \\
(0.105)\end{array}$ & $\begin{array}{c}0.222 * * \\
(0.105)\end{array}$ & $\begin{array}{c}0.243^{* *} \\
(0.105)\end{array}$ & $\begin{array}{l}0.22^{* *} \\
(0.106)\end{array}$ & $\begin{array}{c}0.37 * * * \\
(0.131)\end{array}$ & $\begin{array}{c}0.323 * * \\
(0.137)\end{array}$ & $\begin{array}{c}0.077 \\
(0.365)\end{array}$ & $\begin{array}{l}-0.023 \\
(0.364)\end{array}$ \\
\hline & Lag Academic R\&D & $\begin{array}{c}0.340 \\
(0.515)\end{array}$ & $\begin{array}{c}0.251 \\
(0.524)\end{array}$ & $\begin{array}{c}0.338 \\
(0.514)\end{array}$ & $\begin{array}{c}0.250 \\
(0.524)\end{array}$ & $\begin{array}{l}-0.555 \\
(0.643)\end{array}$ & $\begin{array}{l}-0.793 \\
(0.714)\end{array}$ & $\begin{array}{l}-0.222 \\
(1.294)\end{array}$ & $\begin{array}{l}-0.481 \\
(1.375)\end{array}$ \\
\hline & Corporate - Income Taxes & $\begin{array}{l}-5.095 \\
(3.322)\end{array}$ & $\begin{array}{l}-4.534 \\
(3.241)\end{array}$ & $\begin{array}{l}-4.821 \\
(3.279)\end{array}$ & $\begin{array}{l}-4.263 \\
(3.197)\end{array}$ & $\begin{array}{l}-3.865 \\
(3.355)\end{array}$ & $\begin{array}{c}-3.371 \\
(3.580)\end{array}$ & $\begin{array}{l}-13.032 \\
(8.133)\end{array}$ & $\begin{array}{l}-10.458 \\
(8.814)\end{array}$ \\
\hline & $\mathrm{N}$ & 778 & 733 & 778 & 733 & 778 & 733 & 778 & 733 \\
\hline & R-square & 0.751 & 0.755 & 0.749 & 0.753 & 0.610 & 0.638 & 0.673 & 0.694 \\
\hline
\end{tabular}


Table 3. Panel B.

\begin{tabular}{|c|c|c|c|c|c|c|c|c|c|}
\hline \multirow{2}{*}{$\begin{array}{l}\text { Firm size } \\
\text { category }\end{array}$} & & \multicolumn{2}{|c|}{ Pct Firms } & \multicolumn{2}{|c|}{ Pct Establishment } & \multicolumn{2}{|c|}{ Pct Employment } & \multicolumn{2}{|c|}{ Pct Payroll } \\
\hline & & (1) & (2) & (3) & (4) & (5) & (6) & (7) & (8) \\
\hline \multirow[t]{28}{*}{ 5-19 } & Pct SBL & -0.122 & -0.123 & -0.120 & -0.126 & -0.132 & -0.207 & 0.000 & -0.087 \\
\hline & & $(0.263)$ & $(0.267)$ & $(0.258)$ & $(0.261)$ & $(0.395)$ & $(0.384)$ & $(0.374)$ & $(0.385)$ \\
\hline & Pct VCD & $0.003 * * *$ & $0.003^{* * *}$ & $0.003^{* * *}$ & $0.003^{* * *}$ & 0.001 & 0.001 & 0.001 & 0.001 \\
\hline & & $(0.001)$ & $(0.001)$ & $(0.001)$ & $(0.001)$ & $(0.002)$ & $(0.002)$ & $(0.002)$ & $(0.002)$ \\
\hline & Pct Personal Income & $16.862 * * *$ & $17.631^{* * *}$ & $16.291 * * *$ & $17.131^{* * *}$ & $14.388 * * *$ & $16.827 * * *$ & $33.795 * * *$ & $34.401 * * *$ \\
\hline & & $(4.290)$ & $(4.246)$ & $(4.058)$ & $(4.025)$ & $(5.326)$ & (5.219) & $(4.892)$ & $(5.108)$ \\
\hline & Education & -0.728 & -0.940 & -0.710 & -0.917 & -1.262 & -0.939 & 0.883 & 0.721 \\
\hline & & $(2.841)$ & $(2.894)$ & $(2.768)$ & $(2.787)$ & $(4.034)$ & $(4.336)$ & $(4.114)$ & $(4.215)$ \\
\hline & Log(Patent 20yr) & -0.238 & -0.197 & -0.227 & -0.185 & -0.256 & -0.260 & $-0.773 * * *$ & $-0.734 * * *$ \\
\hline & & $(0.249)$ & $(0.265)$ & $(0.252)$ & $(0.266)$ & $(0.361)$ & $(0.344)$ & $(0.276)$ & $(0.272)$ \\
\hline & Homestead Exemption & 0.000 & -0.004 & 0.000 & -0.005 & -0.003 & 0.001 & 0.004 & 0.000 \\
\hline & & $(0.056)$ & $(0.058)$ & $(0.058)$ & $(0.060)$ & $(0.059)$ & $(0.061)$ & $(0.060)$ & $(0.060)$ \\
\hline & Size of Government Index & $0.914^{* * *}$ & $0.941^{* * *}$ & $0.913 * * *$ & $0.941 * * *$ & $0.878 * * *$ & $0.959 * * *$ & 0.286 & 0.313 \\
\hline & & $(0.298)$ & $(0.312)$ & $(0.295)$ & $(0.308)$ & $(0.308)$ & $(0.315)$ & $(0.406)$ & $(0.420)$ \\
\hline & Takings and Dis. Tax Index & -0.470 & -0.490 & -0.437 & -0.459 & -0.425 & -0.552 & 0.050 & 0.089 \\
\hline & & $(0.357)$ & $(0.374)$ & $(0.347)$ & $(0.362)$ & $(0.386)$ & $(0.393)$ & $(0.296)$ & $(0.308)$ \\
\hline & Labor Freedom Index & $1.087 * *$ & $1.11^{* *}$ & $1.037 * *$ & $1.06^{* *}$ & $1.49 * * *$ & $1.523^{* * *}$ & $2.221^{* * *}$ & $2.099 * * *$ \\
\hline & & $(0.416)$ & $(0.423)$ & $(0.412)$ & $(0.417)$ & $(0.435)$ & $(0.441)$ & $(0.533)$ & $(0.528)$ \\
\hline & Lag NBIA/Pop & 0.202 & 0.165 & 0.227 & 0.199 & 0.302 & 0.363 & $0.692^{*}$ & $0.687^{*}$ \\
\hline & & $(0.227)$ & $(0.245)$ & $(0.221)$ & $(0.241)$ & $(0.294)$ & $(0.296)$ & $(0.354)$ & $(0.365)$ \\
\hline & Lag SBIR/Pop & $0.32 * *$ & $0.331 * *$ & $0.328 * *$ & $0.335 * *$ & $0.366^{* *}$ & $0.41^{* *}$ & $0.588 * * *$ & $0.524^{* * *}$ \\
\hline & & $(0.129)$ & $(0.136)$ & $(0.123)$ & $(0.129)$ & $(0.149)$ & $(0.168)$ & $(0.142)$ & $(0.153)$ \\
\hline & Lag Academic R\&D & -0.434 & -0.434 & -0.453 & -0.447 & -0.376 & -0.194 & -0.439 & -0.533 \\
\hline & & $(0.648)$ & $(0.712)$ & $(0.630)$ & $(0.692)$ & $(0.776)$ & $(0.844)$ & $(0.774)$ & $(0.785)$ \\
\hline & Corporate - Income Taxes & -0.832 & -2.089 & -0.929 & -2.076 & -1.731 & -3.170 & -2.341 & -2.909 \\
\hline & & (3.107) & (3.245) & (3.219) & (3.325) & (3.595) & (3.560) & (5.189) & (5.204) \\
\hline & $\mathrm{N}$ & 778 & 733 & 778 & 733 & 778 & 733 & 778 & 733 \\
\hline & R-square & 0.755 & 0.758 & 0.743 & 0.746 & 0.637 & 0.680 & 0.767 & 0.773 \\
\hline
\end{tabular}


Table 3. Panel C.

\begin{tabular}{|c|c|c|c|c|c|c|c|c|c|}
\hline \multirow{2}{*}{$\begin{array}{l}\text { Firm size } \\
\text { category }\end{array}$} & & \multicolumn{2}{|c|}{ Pct Firms } & \multicolumn{2}{|c|}{ Pct Establishment } & \multicolumn{2}{|c|}{ Pct Employment } & \multicolumn{2}{|c|}{ Pct Payroll } \\
\hline & & (1) & (2) & (3) & (4) & (5) & (6) & (7) & (8) \\
\hline \multirow[t]{28}{*}{$20-99$} & Pct SBL & -0.096 & 0.012 & 0.058 & 0.163 & -0.259 & -0.176 & -0.412 & -0.320 \\
\hline & & $(0.539)$ & $(0.549)$ & $(0.551)$ & $(0.561)$ & $(0.539)$ & $(0.552)$ & $(0.496)$ & $(0.524)$ \\
\hline & Pct VCD & $0.004 * *$ & $0.004 * *$ & 0.002 & 0.002 & $0.004 * *$ & $0.004 * *$ & $0.006 * * *$ & $0.006 * * *$ \\
\hline & & $(0.002)$ & $(0.002)$ & $(0.002)$ & $(0.002)$ & $(0.002)$ & $(0.002)$ & $(0.002)$ & $(0.002)$ \\
\hline & Pct Personal Income & $29.865 * * *$ & $29.418 * * *$ & $22.692 * * *$ & $21.955 * * *$ & $34.46 * * *$ & $34.452 * * *$ & $47.078 * * *$ & $46.296 * * *$ \\
\hline & & $(6.536)$ & $(6.516)$ & $(6.446)$ & $(6.605)$ & $(6.713)$ & $(6.534)$ & $(4.957)$ & $(5.202)$ \\
\hline & Education & 2.046 & 3.561 & 2.672 & 4.599 & 3.705 & 6.695 & -2.919 & 0.879 \\
\hline & & $(5.146)$ & $(5.251)$ & $(5.264)$ & $(5.260)$ & $(5.249)$ & $(5.579)$ & $(6.444)$ & $(6.651)$ \\
\hline & Log(Patent 20yr) & 0.016 & -0.018 & -0.236 & -0.338 & 0.030 & 0.055 & -0.393 & -0.418 \\
\hline & & $(0.376)$ & $(0.377)$ & $(0.366)$ & $(0.372)$ & $(0.450)$ & $(0.424)$ & $(0.603)$ & $(0.582)$ \\
\hline & Homestead Exemption & -0.024 & -0.034 & -0.020 & -0.031 & -0.033 & -0.039 & -0.014 & -0.026 \\
\hline & & $(0.034)$ & $(0.035)$ & $(0.038)$ & $(0.037)$ & $(0.035)$ & $(0.035)$ & $(0.038)$ & $(0.037)$ \\
\hline & Size of Government Index & $0.667^{*}$ & $0.649 *$ & 0.289 & 0.237 & 0.562 & 0.544 & -0.075 & -0.062 \\
\hline & & $(0.336)$ & $(0.351)$ & $(0.318)$ & $(0.331)$ & $(0.372)$ & $(0.391)$ & $(0.448)$ & $(0.470)$ \\
\hline & Takings and Dis. Tax Index & -0.685 & -0.722 & -0.333 & -0.334 & -0.848 & -0.866 & -0.245 & -0.183 \\
\hline & & $(0.443)$ & $(0.464)$ & $(0.432)$ & $(0.452)$ & $(0.517)$ & $(0.538)$ & $(0.410)$ & $(0.413)$ \\
\hline & Labor Freedom Index & $1.904^{* * *}$ & $1.991 * * *$ & $1.692 * * *$ & $1.704 * * *$ & $1.998 * * *$ & $2.104^{* * *}$ & $2.815 * * *$ & $2.721^{* * *}$ \\
\hline & & $(0.507)$ & $(0.527)$ & $(0.466)$ & $(0.472)$ & $(0.550)$ & $(0.572)$ & $(0.806)$ & $(0.809)$ \\
\hline & Lag NBIA/Pop & -0.144 & -0.182 & -0.255 & -0.307 & -0.108 & -0.169 & -0.024 & -0.093 \\
\hline & & $(0.362)$ & $(0.377)$ & $(0.389)$ & $(0.402)$ & $(0.430)$ & $(0.447)$ & $(0.490)$ & $(0.521)$ \\
\hline & Lag SBIR/Pop & $0.597 * * *$ & $0.642 * * *$ & $0.51 * * *$ & $0.532 * * *$ & $0.472 * *$ & $0.515 * * *$ & $0.686 * * *$ & $0.671^{* * *}$ \\
\hline & & $(0.181)$ & $(0.189)$ & $(0.178)$ & $(0.181)$ & $(0.180)$ & $(0.187)$ & $(0.154)$ & $(0.155)$ \\
\hline & Lag Academic R\&D & -0.430 & -0.304 & -0.631 & -0.558 & -0.669 & -0.589 & -0.032 & -0.227 \\
\hline & & $(0.624)$ & $(0.683)$ & $(0.634)$ & $(0.680)$ & $(0.690)$ & $(0.790)$ & $(0.927)$ & $(1.011)$ \\
\hline & Corporate - Income Taxes & 2.776 & 2.611 & -0.629 & -0.627 & 2.672 & 2.078 & 5.250 & 6.011 \\
\hline & & (5.563) & (5.898) & (3.941) & (4.243) & (6.493) & (6.935) & (7.123) & (7.510) \\
\hline & $\mathrm{N}$ & 778 & 733 & 778 & 733 & 778 & 733 & 778 & 733 \\
\hline & R-square & 0.760 & 0.760 & 0.807 & 0.813 & 0.778 & 0.774 & 0.897 & 0.894 \\
\hline
\end{tabular}




\section{Table 4: First-Stage Instrumental Variable Regression for Bank Loan Supply and Venture Capital Supply}

The table presents the first-stage instrumental variable (IV) regressions for venture capital supply and bank loan supply, respectively. Panel A reports the first-stage instrumental variable regression for venture capital supply, following Samila and Sorenson (2010). The dependent variable is growth rate of total venture capital investment. The independent variables are LP Returns, logarithm of population, as well as state and year fixed effects. $L P$ Returns is constructed by multiplying the national average percentage returns to college and university endowments by the number of limited partners in each region that had invested in any private equity fund at least ten years earlier using data from the Chronicle of Higher Education and VentureXpert. Panel B reports the IV regression. The dependent variable is logarithm of amount of small bank lending. Adj. Capital Ratio is defined as the fraction of banks with adjusted capital ratios less than $4 \%$, where the adjusted capital ratio is defined as total equity plus loan loss reserves minus nonperforming asset scaled by total assets. HHI is the deposit Herfindahl-Hirschmann index, calculated as the sum of squared market shares based on branch-level deposit data from the FDIC's Summary of Deposits Survey, similar to the method in Black and Strahan (JF,2002). Pct. Assets $100 \mathrm{M}$ is the fraction of state-level bank assets held by banks with assets less than 100 million dollars, and Pct. Assets $300 \mathrm{M}$ is the fraction of statelevel bank assets held by banks with assets less than 300 million dollars. The latter two variables are constructed using data from the FFIEC's Report of Income and Condition. Both models include both state and year fixed effects. Standard errors are in parentheses. ***, **, and ${ }^{*}$ denotes significance at the $1 \%, 5 \%$ and $10 \%$ level, respectively.

\section{Panel A:}

\begin{tabular}{cc} 
Parameter & Estimate \\
\hline Log(population) & $-3.350^{* * *}$ \\
& $(0.271)$ \\
LP Returns & $2.249^{* * *}$ \\
& $(0.666)$
\end{tabular}

\section{Panel B:}

Parameter

Adj. Capital ratio

Estimate

$1.604 * * *$

(0.414)

Pct assets 100M

$-6.134 * * *$

(0.439)

$3.050 * * *$

(0.676)

Pct assets 300M

$-4.104 * * *$ 
Table 5. Instrumental Variable Regressions

The table shows the coefficient estimates from the instrumental variable regressions for the growth rate of number of firms in column (1) and (2), growth rate of number of establishments in column (3) and (4), growth rate of number of employees in column (5) and (6), and growth rate of number of payroll in thousands of dollars in column (7) and (8). Pct VCD hat is estimated using the model in Panel A of Table 5. Pct SBL hat is estimated using the model in Panel B of Table 5. The full sample is 50 U.S. states between 1995 and 2011. Models (1), (3), (5) and (7) are based the full sample, while models (2), (4), (6) and (8) exclude the year 2000. All regressions control for year and state fixed effects. Standard errors are in parentheses. ***, **, and * denotes significance at the $1 \%$, $5 \%$ and 10\% level, respectively. All variables are defined in Table 1.

\begin{tabular}{|c|c|c|c|c|c|c|c|c|c|}
\hline \multirow{2}{*}{$\begin{array}{l}\text { Firm size } \\
\text { category }\end{array}$} & & \multicolumn{2}{|c|}{ Pct Firms } & \multicolumn{2}{|c|}{ Pct Establishment } & \multicolumn{2}{|c|}{ Pct Employment } & \multicolumn{2}{|c|}{ Pct Payroll } \\
\hline & & (1) & (2) & (3) & (4) & (5) & (6) & (7) & (8) \\
\hline \multirow[t]{28}{*}{$0-4$} & Pct SBL hat & 2.585 & 2.243 & 2.810 & 2.443 & 2.806 & 2.692 & -5.000 & -7.703 \\
\hline & & $(4.753)$ & $(4.948)$ & $(4.705)$ & $(4.888)$ & (3.716) & (3.955) & $(14.216)$ & $(14.976)$ \\
\hline & Pct VCD hat & 0.089 & 0.058 & 0.088 & 0.055 & -0.208 & -0.251 & 0.304 & -0.087 \\
\hline & & $(0.139)$ & $(0.138)$ & $(0.139)$ & $(0.138)$ & $(0.150)$ & $(0.167)$ & $(0.390)$ & $(0.432)$ \\
\hline & Pct Personal Income & $14.979 * * *$ & $15.056 * * *$ & $14.962 * * *$ & $15.043^{* * *}$ & $18.851^{* * *}$ & $18.328 * * *$ & $28.593 * * *$ & $27.502 * * *$ \\
\hline & & $(3.337)$ & $(3.375)$ & $(3.310)$ & $(3.346)$ & $(3.260)$ & (3.677) & $(7.406)$ & (7.935) \\
\hline & Education & $6.405^{*}$ & $6.758^{*}$ & $6.531 *$ & $6.858^{*}$ & 6.619 & 7.024 & -13.149 & -13.954 \\
\hline & & $(3.760)$ & (3.915) & $(3.760)$ & $(3.900)$ & $(4.996)$ & $(5.503)$ & $(12.448)$ & $(12.682)$ \\
\hline & Log(Patent 20yr) & -0.679 & $-0.789 *$ & -0.697 & $-0.812 *$ & -0.738 & -0.806 & $-1.639 * *$ & $-2.184 * * *$ \\
\hline & & $(0.453)$ & $(0.457)$ & $(0.450)$ & $(0.455)$ & $(0.494)$ & $(0.519)$ & $(0.653)$ & $(0.712)$ \\
\hline & Homestead Exemption & -0.021 & -0.019 & -0.019 & -0.018 & 0.000 & 0.000 & -0.011 & -0.005 \\
\hline & & $(0.042)$ & $(0.042)$ & $(0.041)$ & $(0.042)$ & $(0.047)$ & $(0.049)$ & $(0.059)$ & $(0.059)$ \\
\hline & Size of Government Index & 0.201 & 0.216 & 0.197 & 0.212 & $0.685 * * *$ & $0.672 * * *$ & -0.137 & -0.002 \\
\hline & & $(0.199)$ & $(0.195)$ & $(0.199)$ & $(0.194)$ & $(0.230)$ & $(0.240)$ & $(0.661)$ & $(0.709)$ \\
\hline & Takings and Dis. Tax Index & -0.102 & -0.084 & -0.115 & -0.095 & -0.553 & -0.417 & -0.044 & 0.081 \\
\hline & & $(0.280)$ & $(0.284)$ & $(0.280)$ & $(0.284)$ & $(0.364)$ & $(0.385)$ & $(0.603)$ & $(0.576)$ \\
\hline & Labor Freedom Index & $1.101 * * *$ & $1.108 * * *$ & $1.085 * * *$ & $1.088 * * *$ & 0.490 & 0.464 & $1.715^{*}$ & 1.193 \\
\hline & & $(0.370)$ & $(0.383)$ & $(0.374)$ & $(0.387)$ & $(0.393)$ & $(0.436)$ & $(0.930)$ & $(0.957)$ \\
\hline & Lag NBIA/Pop & $0.537^{*}$ & $0.556^{*}$ & $0.547^{*}$ & $0.57 *$ & 0.367 & 0.400 & -0.028 & 0.564 \\
\hline & & $(0.285)$ & $(0.303)$ & $(0.290)$ & $(0.309)$ & $(0.303)$ & $(0.359)$ & $(0.723)$ & $(0.678)$ \\
\hline & Lag SBIR/Pop & $0.217 * *$ & $0.196 *$ & $0.217 * *$ & $0.197^{*}$ & $0.36 * *$ & $0.309 * *$ & -0.019 & -0.109 \\
\hline & & $(0.105)$ & $(0.107)$ & $(0.105)$ & $(0.107)$ & $(0.134)$ & $(0.143)$ & $(0.373)$ & $(0.382)$ \\
\hline & Lag Academic R\&D & 0.416 & 0.336 & 0.417 & 0.338 & -0.508 & -0.742 & -0.104 & -0.319 \\
\hline & & $(0.524)$ & $(0.535)$ & $(0.525)$ & $(0.537)$ & $(0.660)$ & $(0.740)$ & $(1.245)$ & $(1.391)$ \\
\hline & Corporate - Income Taxes & -3.251 & -2.702 & -3.065 & -2.516 & -2.219 & -1.739 & -14.929 & -12.226 \\
\hline & & $(3.596)$ & (3.537) & (3.581) & (3.524) & (3.600) & (3.955) & $(9.072)$ & (9.834) \\
\hline & $\mathrm{N}$ & 746 & 701 & 746 & 701 & 746 & 701 & 746 & 701 \\
\hline & R-square & 0.743 & 0.746 & 0.741 & 0.744 & 0.623 & 0.654 & 0.673 & 0.696 \\
\hline
\end{tabular}


Table 5. Panel B.

\begin{tabular}{|c|c|c|c|c|c|c|c|c|c|}
\hline \multirow{2}{*}{$\begin{array}{l}\text { Firm size } \\
\text { category }\end{array}$} & & \multicolumn{2}{|c|}{ Pct Firms } & \multicolumn{2}{|c|}{ Pct Establishment } & \multicolumn{2}{|c|}{ Pct Employment } & \multicolumn{2}{|c|}{ Pct Payroll } \\
\hline & & (1) & $(2)$ & (3) & $(4)$ & (5) & (6) & (7) & $(8)$ \\
\hline \multirow[t]{28}{*}{ 5-19 } & Pct SBL hat & -1.696 & -1.729 & -2.319 & -2.456 & -4.212 & -6.041 & -0.113 & -0.936 \\
\hline & & $(3.012)$ & (3.398) & $(3.124)$ & $(3.510)$ & $(4.340)$ & $(4.720)$ & $(5.006)$ & $(5.120)$ \\
\hline & Pct VCD hat & $0.262 * * *$ & $0.294^{* * *}$ & $0.228 * *$ & $0.258 * *$ & $0.289 * * *$ & $0.333^{* *}$ & $0.392 * *$ & $0.338 * *$ \\
\hline & & $(0.098)$ & $(0.103)$ & $(0.095)$ & $(0.101)$ & $(0.105)$ & $(0.126)$ & $(0.154)$ & $(0.158)$ \\
\hline & Pct Personal Income & $16.231 * * *$ & $17.025 * * *$ & $15.929 * * *$ & $16.795 * * *$ & $14.228 * *$ & $16.538 * * *$ & $33.514 * * *$ & $34.688 * * *$ \\
\hline & & $(4.328)$ & $(4.170)$ & $(4.081)$ & $(3.934)$ & $(5.618)$ & $(5.444)$ & $(4.589)$ & $(4.761)$ \\
\hline & Education & 1.235 & 0.987 & 1.207 & 0.987 & 1.560 & 2.131 & 1.479 & 1.128 \\
\hline & & $(3.247)$ & $(3.300)$ & (3.163) & (3.186) & $(3.765)$ & $(4.031)$ & $(3.760)$ & $(3.764)$ \\
\hline & Log(Patent 20yr) & $-0.707 * * *$ & $-0.697 * * *$ & $-0.678 * * *$ & $-0.667 * *$ & -0.505 & -0.565 & $-1.144 * * *$ & $-1.121 * * *$ \\
\hline & & $(0.239)$ & $(0.254)$ & $(0.242)$ & $(0.257)$ & $(0.399)$ & $(0.386)$ & $(0.318)$ & $(0.317)$ \\
\hline & Homestead Exemption & 0.002 & -0.004 & 0.001 & -0.004 & -0.004 & 0.001 & 0.002 & -0.002 \\
\hline & & $(0.059)$ & $(0.061)$ & $(0.061)$ & $(0.062)$ & $(0.060)$ & $(0.062)$ & $(0.060)$ & $(0.060)$ \\
\hline & Size of Government Index & $0.886 * * *$ & $0.917 * * *$ & $0.879 * * *$ & $0.911^{* * *}$ & $0.832 * * *$ & $0.907 * * *$ & 0.243 & 0.292 \\
\hline & & $(0.300)$ & $(0.315)$ & $(0.297)$ & $(0.312)$ & $(0.298)$ & $(0.306)$ & $(0.392)$ & $(0.412)$ \\
\hline & Takings and Dis. Tax Index & -0.507 & -0.524 & -0.472 & -0.491 & -0.470 & -0.607 & -0.050 & -0.010 \\
\hline & & $(0.355)$ & $(0.371)$ & $(0.346)$ & $(0.361)$ & $(0.385)$ & $(0.388)$ & $(0.280)$ & $(0.292)$ \\
\hline & Labor Freedom Index & $1.002 * *$ & $1.019 * *$ & $0.944 * *$ & $0.961 * *$ & $1.436 * * *$ & $1.47 * * *$ & $2.11^{* * *}$ & $1.988 * * *$ \\
\hline & & $(0.426)$ & $(0.436)$ & $(0.422)$ & $(0.430)$ & $(0.452)$ & $(0.462)$ & $(0.530)$ & $(0.530)$ \\
\hline & Lag NBIA/Pop & 0.225 & 0.196 & 0.252 & 0.231 & 0.309 & 0.369 & $0.709 *$ & $0.721^{*}$ \\
\hline & & $(0.252)$ & $(0.268)$ & $(0.243)$ & $(0.259)$ & $(0.308)$ & $(0.312)$ & $(0.362)$ & $(0.369)$ \\
\hline & Lag SBIR/Pop & $0.306 * *$ & $0.314^{* *}$ & $0.312 * *$ & $0.315^{* *}$ & $0.378 * *$ & $0.428 * *$ & $0.597 * * *$ & $0.533 * * *$ \\
\hline & & $(0.128)$ & $(0.133)$ & $(0.123)$ & $(0.127)$ & $(0.155)$ & $(0.177)$ & $(0.151)$ & $(0.164)$ \\
\hline & Lag Academic R\&D & -0.404 & -0.385 & -0.435 & -0.412 & -0.334 & -0.154 & -0.167 & -0.217 \\
\hline & & $(0.636)$ & $(0.688)$ & $(0.624)$ & $(0.673)$ & $(0.778)$ & $(0.819)$ & $(0.787)$ & $(0.796)$ \\
\hline & Corporate - Income Taxes & -2.937 & -4.392 & -3.033 & -4.357 & -4.027 & -5.887 & -3.280 & -4.035 \\
\hline & & (3.098) & (3.335) & (3.184) & (3.381) & (3.584) & (3.597) & (5.377) & (5.420) \\
\hline & $\mathrm{N}$ & 746 & 701 & 746 & 701 & 746 & 701 & 746 & 701 \\
\hline & R-square & 0.754 & 0.757 & 0.744 & 0.748 & 0.626 & 0.674 & 0.774 & 0.779 \\
\hline
\end{tabular}




\begin{tabular}{|c|c|c|c|c|c|c|c|c|c|}
\hline \multirow{2}{*}{$\begin{array}{l}\text { Firm size } \\
\text { category }\end{array}$} & & \multicolumn{2}{|c|}{ Pct Firms } & \multicolumn{2}{|c|}{ Pct Establishment } & \multicolumn{2}{|c|}{ Pct Employment } & \multicolumn{2}{|c|}{ Pct Payroll } \\
\hline & & (1) & (2) & (3) & (4) & (5) & (6) & (7) & (8) \\
\hline \multirow[t]{28}{*}{$20-99$} & Pct SBL hat & 2.590 & 4.153 & $10.986 *$ & $12.199 *$ & 8.129 & 9.212 & $13.698 *$ & $15.014^{*}$ \\
\hline & & $(5.642)$ & $(6.222)$ & $(6.150)$ & $(6.786)$ & $(6.783)$ & (7.358) & $(7.291)$ & (7.583) \\
\hline & Pct VCD hat & $0.186^{*}$ & 0.211 & 0.018 & -0.002 & 0.199 & 0.250 & $0.588 * * *$ & $0.492 * *$ \\
\hline & & $(0.108)$ & $(0.143)$ & $(0.110)$ & $(0.113)$ & $(0.146)$ & $(0.153)$ & $(0.206)$ & $(0.212)$ \\
\hline & Pct Personal Income & $29.92 * * *$ & $29.351 * * *$ & $23.763 * * *$ & $23.072 * * *$ & $34.241 * * *$ & $34.031 * * *$ & $45.672 * * *$ & $45.53 * * *$ \\
\hline & & $(6.829)$ & $(6.770)$ & $(6.559)$ & $(6.683)$ & (7.019) & $(6.797)$ & $(4.735)$ & $(4.872)$ \\
\hline & Education & 3.224 & 4.980 & 2.751 & 4.928 & 3.738 & 6.892 & -4.823 & -0.970 \\
\hline & & $(5.314)$ & $(5.409)$ & $(5.661)$ & $(5.671)$ & $(5.274)$ & $(5.514)$ & $(6.333)$ & $(6.630)$ \\
\hline & Log(Patent 20yr) & -0.262 & -0.339 & -0.527 & -0.688 & -0.245 & -0.243 & -0.677 & -0.743 \\
\hline & & $(0.425)$ & $(0.423)$ & $(0.422)$ & $(0.426)$ & $(0.507)$ & $(0.478)$ & $(0.777)$ & $(0.758)$ \\
\hline & Homestead Exemption & -0.031 & -0.043 & -0.031 & -0.046 & -0.039 & -0.047 & -0.015 & -0.029 \\
\hline & & $(0.038)$ & $(0.040)$ & $(0.039)$ & $(0.040)$ & $(0.038)$ & $(0.039)$ & $(0.044)$ & $(0.044)$ \\
\hline & Size of Government Index & $0.642 *$ & 0.617 & 0.268 & 0.210 & 0.496 & 0.469 & -0.143 & -0.108 \\
\hline & & $(0.358)$ & $(0.375)$ & $(0.346)$ & $(0.362)$ & $(0.403)$ & $(0.425)$ & $(0.442)$ & $(0.469)$ \\
\hline & Takings and Dis. Tax Index & -0.642 & -0.673 & -0.244 & -0.240 & -0.821 & -0.835 & -0.162 & -0.080 \\
\hline & & $(0.458)$ & $(0.478)$ & $(0.448)$ & $(0.466)$ & $(0.533)$ & $(0.554)$ & $(0.414)$ & $(0.411)$ \\
\hline & Labor Freedom Index & $1.924 * * *$ & $2.017 * * *$ & $1.671^{* * *}$ & $1.686 * * *$ & $1.944^{* * *}$ & $2.05 * * *$ & $2.698 * * *$ & $2.622 * * *$ \\
\hline & & $(0.539)$ & $(0.557)$ & $(0.506)$ & $(0.516)$ & $(0.570)$ & $(0.588)$ & $(0.806)$ & $(0.811)$ \\
\hline & Lag NBIA/Pop & -0.092 & -0.118 & -0.339 & -0.386 & -0.129 & -0.183 & -0.087 & -0.135 \\
\hline & & $(0.391)$ & $(0.412)$ & $(0.422)$ & $(0.434)$ & $(0.470)$ & $(0.496)$ & $(0.539)$ & $(0.578)$ \\
\hline & Lag SBIR/Pop & $0.511 * * *$ & $0.557 * * *$ & $0.42 * *$ & $0.443^{* *}$ & $0.386 * *$ & $0.428 * *$ & $0.511^{* * *}$ & $0.494 * * *$ \\
\hline & & $(0.186)$ & $(0.194)$ & $(0.197)$ & $(0.200)$ & $(0.176)$ & $(0.180)$ & $(0.151)$ & $(0.150)$ \\
\hline & Lag Academic R\&D & -0.261 & -0.109 & -0.323 & -0.229 & -0.357 & -0.258 & 0.360 & 0.210 \\
\hline & & $(0.628)$ & $(0.679)$ & $(0.633)$ & $(0.674)$ & $(0.646)$ & $(0.731)$ & $(0.895)$ & $(0.974)$ \\
\hline & Corporate - Income Taxes & 2.127 & 1.967 & -0.397 & -0.423 & 2.727 & 2.102 & 6.058 & 6.900 \\
\hline & & $(5.736)$ & (6.175) & (4.087) & $(4.410)$ & (6.723) & (7.277) & (7.542) & (7.979) \\
\hline & $\mathrm{N}$ & 746 & 701 & 746 & 701 & 746 & 701 & 746 & 701 \\
\hline & R-square & 0.744 & 0.744 & 0.809 & 0.815 & 0.758 & 0.753 & 0.893 & 0.888 \\
\hline
\end{tabular}

